\title{
Effects of dietary antioxidant of tomato extract and lycopene on Carassius auratus and Xiphophorus maculatus
}

\author{
Efecto antioxidante de un extracto de jitomate y licopeno en \\ Carassius auratus y Xiphophorus maculatus
}

\author{
Cynthia Montoya $M,{ }^{1} \mathrm{IQ}$, Fernando Vega $\mathrm{V}_{1}{ }^{1} \mathrm{Ph} . \mathrm{D}$, Héctor Nolasco $\mathrm{S},{ }^{2 *} \mathrm{Ph} . \mathrm{D}$, \\ Luis Espinosa C, ${ }^{1}$ M.Sc, Olimpia Carrillo $F^{3}$ Ph.D, Felicitas Olvera U, ${ }^{1}$ Lic. Biol.
}

\begin{abstract}
${ }^{1}$ Universidad de Guadalajara. Centro Universitario de la Costa. Laboratorio de Acuicultura Experimental, Av. Universidad No. 203, Puerto Vallarta, Jalisco, México. ${ }^{2}$ Centro de Investigaciones Biológicas del Noroeste, Laboratorio de Fisiología Comparada, Instituto Politécnico Nacional No. 195, La Paz, B.C.S. México. '3universidad de La Habana, Grupo de Biotecnología Marina, La Habana, Cuba. *Correspondence: hnolasco04@cibnor.mx
\end{abstract}

Received: March 2013; Accepted: November 2013.

\begin{abstract}
Objective. Evaluate the effect on tegument pigmentation, survival, growth and antioxidant capacity in diets supplemented with tomato extract and lycopene as additives in experimental feed for Carassius auratus and Xiphophorus maculatus. Materials and methods. The additives were added in different concentrations to a basic diet. We performed beginning and an ending biometrics for $100 \%$ of the population in each bioassay. The growth and survival of organisms were evaluated. The antioxidant capacity was analyzed by ABTS assay, both in the tomato extract sample as well as in foods used in different bioassays. The concentration of lycopene was determined in food and liver and muscle samples of fish fed with it. Acquired pigmentation of fish was assessed through photographs analyzed with Adobe Photoshop ${ }^{\circledR}$. The results were evaluated by analysis of variance, and when differences were found $(p<0.05)$ the means were compared by the Tukey test. Results. No significant effect $(p>0.05)$ on pigmentation and growth of the organisms under the established experimental conditions was obtained. Significant differences in antioxidant capacity $(p<0.05)$ were obtained in foods with added lycopene. Conclusions. The inclusion of lycopene or tomato extract in food for the organisms used is not recommended to improve pigmentation, but further studies are needed to demonstrate antioxidant effect.
\end{abstract}

Key words: Antioxidants, carotenoids, pigmentation, tomato (Source: $C A B$ ).

\section{RESUMEN}

Objetivo. Evaluar el efecto sobre la coloración de la piel, la sobrevivencia, el crecimiento y la capacidad antioxidante por dietas suplementadas con extracto de jitomate y licopeno como aditivos en la alimentación de Carassius auratus y de Xiphophorus maculatus. Materiales y métodos. Los aditivos se añadieron en diferentes concentraciones a una dieta base. Se realizó una biometría inicial y una final del $100 \%$ de la población en cada bioensayo. Se evaluó el crecimiento y supervivencia de los organismos. La capacidad antioxidante se analizó a través del ensayo ABTS, tanto a la muestra 
de extracto de jitomate como a los alimentos utilizados en diferentes bioensayos. Se determinó la concentración de licopeno a los alimentos y en muestras de hígado y músculo de peces alimentados con ellos. La pigmentación adquirida por los peces se evaluó a través de fotografías analizadas con el programa de Adobe Photoshop ${ }^{\circledR}$. Los resultados fueron evaluados con análisis de varianza, cuando se encontraron diferencias $(p<0.05)$ las medias fueron comparadas mediante la prueba de Tukey. Resultados. No se obtuvo un efecto significativo $(p>0.05)$ sobre la pigmentación y el crecimiento de los organismos en estudio bajo las condiciones experimentales establecidas. Se obtuvieron diferencias significativas $(p<0.05)$ en la capacidad antioxidante en los alimentos adicionados con licopeno. Conclusiones. La inclusión de licopeno o de extracto de jitomate en alimentos para los organismos utilizados no es recomendable con el fin de mejorar la pigmentación, aunque se requieren otros estudios para demostrar su efecto antioxidante.

Palabras clave: Antioxidantes, carotenoides, pigmentación, tomate (Fuente: $C A B$ ).

\section{INTRODUCTION}

In aquatic products, the color of skin and muscle is one of the main indicators of quality and affects the consumer's acceptance of the product and the price of the fish; for example, in salmon, color constitutes one of the most important criteria for quality when commercializing the product, in addition to fatty content and texture.

Carotenoids plays an important role in pigmentation of the skin and muscle color in fish. As in other animals, fish do not have the capacity to biosynthesize carotenoids, but must modify dietary carotenoids and store them in tegument and other tissues. Cultivated fish do not have access to a diet rich in carotenoids, and therefore it is necessary to add those compounds to their diet (1).

Due to the high cost and possible toxicity of synthetic pigments, the investigation in the use of yeast (2), marine bacteria, green algae (3), and plant extracts (4) as sources of natural pigment to give fish a bright color.

Carotenoids constitute one of the most important pigments in fish, and have a wide variety of functions including protection against adverse illumination, acting as a ProVitamin A, improving immune response, reproduction, growth, and maturity, regulation of chemotaxis in spermatozoids and is also a powerful antioxidants (5).

Lycopene is one of the first carotenoids that appear in the synthetic route, constituting of a molecular base for the synthesis of other carotenoids. Lycopene, which gives tomato its red color, is also a powerful antioxidant, combating oxidative stress and pathologies associated with it (6).

\section{INTRODUCCIÓN}

En los productos acuícolas, el color de la piel y del músculo es uno de los principales indicadores de calidad y que afecta la aceptación del consumidor y los precios de los peces; por ejemplo en el salmón el color constituye uno de los criterios de calidad más importantes al momento de la comercialización, junto con el contenido graso y la textura.

Los carotenoides juegan un papel importante en la pigmentación de la piel y color del músculo de los peces. Al igual que otros animales, los peces no poseen la capacidad de biosintetizar carotenoides, sino que pueden modificar los carotenoides alimentarios y almacenarlos en el tegumento y otros tejidos. Los peces bajo condiciones de cultivo no tienen acceso a una alimentación rica en carotenoides y, por tanto, es necesario agregar estos compuestos en su dieta (1).

Debido al elevado costo y posible toxicidad de los pigmentos sintéticos, se ha fomentado la investigación del uso de levaduras (2), bacterias marinas, algas verdes (3) y extractos de plantas (4) como fuentes de pigmento naturales para lograr una coloración brillante en los peces.

Los carotenoides constituyen uno de los pigmentos más importantes en peces, estos tienen una amplia variedad de funciones incluyendo la protección frente a condiciones de iluminación adversas, la de actuar como provitamina A, la mejora de la respuesta inmune, de la reproducción, el crecimiento, la maduración, la regulación de la quimiotaxis en los espermatozoides y la de constituir potentes antioxidantes (5).

El licopeno es uno de los primeros carotenoides que aparecen en la ruta sintética, constituyendo la base molecular para la síntesis de otros carotenoides. El licopeno, al cual el jitomate debe su tonalidad roja, es además un poderoso antioxidante, que combate el estrés oxidativo y las patologías asociadas a este (6). 
Carotenoids act as antioxidants due to their capacity to interact with oxygen reactive species, significant among them lycopene. Due to that, ingesting lycopene as an antioxidant in fish could help trap active oxygen species and reduce oxidative stress and the danger of oxidation of cellular components (lipids, proteins and DNA) (7); therefore, many functional foods are currently designed with the objective of providing an elevated amount of antioxidants and reducing the risk of diseases associated with oxidative stress (8).

This investigation was carried out to determine if the use of lycopene and tomato extract in diet could have a double function, as pigmentation as well as an antioxidant, affecting growth and survival of goldfish (C. auratus) and "platy" fishes ( $X$. maculatus).

\section{MATERIALS AND METHODS}

Experiment site. The experiments took place in the Laboratorio de Acuicultura Experimental of the Centro Universitario de la Costa (CUCOSTA), belongs to the Universidad de Guadalajara, in Puerto Vallarta, Jalisco, Mexico. The cultivation water was taken from the municipal system, and left to sit (7 days) to eliminate the excess of chlorine.

Organisms and experimental units (EU). The fish used for the experiment were adult goldfish (Carassius auratus) and "platy" fish (Xiphophorus maculatus) from the installations of the Laboratorio de Acuicultura Experimental. In the EU the $\mathrm{pH}$ parameters were taken (7-8) (potentiometer HANNA Instruments ${ }^{\circledR}$, Distrito Federal, Mexico), dissolved oxygen ( $7.4 \pm 0.4$ $\mathrm{mg} / \mathrm{L}$ ) and temperature $\left(25.1 \pm 2^{\circ} \mathrm{C}\right.$ ) (oximeter $\mathrm{YSI}^{\circledR}$, Yellow Springs, OH 45387 USA) three times a week. The EU were kept well aired. Leftovers of food and fecal matter were cleaned daily. Sex determination was not performed.

\section{Bioassays:}

Bioassay with tomato extract. Seventy eight goldfish (25.9 $\pm 6.8 \mathrm{~g}$ weight and $117.2 \pm 13.5$ $\mathrm{mm}$ length) were distributed randomly in experimental units consisting of $400 \mathrm{~L}$. circular tanks, with flow of filtered water in a filtration system with Aquadyne ${ }^{\circledR}$ spheres and a sterilizer ultraviolet light SmartUV ${ }^{\circledR}$. Three organisms in each one of the $26 \mathrm{EU}$ were used.

Bioassay with lycopene in $\boldsymbol{C}$. auratus. Thirty six goldfish ( $37.8 \pm 10.8 \mathrm{~g}$ weight and $134.0 \pm 12.3$ $\mathrm{mm}$ length) were distributed randomly in EU as
Los carotenoides actúan como antioxidantes debido a su capacidad de interactuar con las especies reactivas de oxígeno, destacando entre todos ellos el licopeno. Por lo anterior, la ingesta de licopeno como antioxidante en los peces pudiera ayudar en atrapar especies activas de oxígeno y reducir el estrés oxidativo y el peligro de oxidación de los componentes celulares (lípidos, proteínas y ADN) (7); así, muchos alimentos funcionales son diseñados actualmente con el objetivo de proporcionar una ingesta elevada de antioxidantes y reducir el riesgo de enfermedades asociadas al estrés oxidativo (8).

La presente investigación se llevó a cabo para determinar si el uso del licopeno y el extracto de jitomate en las dietas podría tener una doble función, como pigmento y antioxidante, influyendo en el crecimiento y sobrevivencia de carpas doradas (C. auratus) y peces "platy" ( $X$. maculatus).

\section{MATERIALES Y MÉTODOS}

Sitio experimental. Los experimentos se llevaron a cabo en el Laboratorio de Acuicultura Experimental del Centro Universitario de la Costa (CUCOSTA), perteneciente a la Universidad de Guadalajara, en Puerto Vallarta, Jalisco, México. El agua de cultivo fue obtenida del sistema municipal, previamente reposada (7 días) para eliminar el exceso de cloro.

Organismos y unidades experimentales (UE). Como peces experimentales se utilizaron ejemplares adultos de carpas doradas (Carassius auratus) y peces "platy" (Xiphophorus maculatus) de las instalaciones del Laboratorio de Acuicultura Experimental. En las UE se tomaron parámetros de $\mathrm{pH}$ (7-8) (potenciómetro HANNA Instruments ${ }^{\circledR}$, Distrito Federal, México), oxígeno disuelto $(7.4 \pm 0.4 \mathrm{mg} / \mathrm{L})$ y temperatura $\left(25.1 \pm 2^{\circ} \mathrm{C}\right.$ ) (oxímetro $\mathrm{YSI}^{\circledR}$, Yellow Springs, OH 45387 USA) tres veces por semana. Las UE se mantuvieron con aireación constante. Los restos de comida y los residuos fecales fueron limpiados diariamente. La determinación de sexo no fue realizada.

\section{Bioensayos:}

Bioensayo con extracto de jitomate. Setenta y ocho carpas doradas $(25.9 \pm 6.8 \mathrm{~g}$ de peso y $117.2 \pm 13.5 \mathrm{~mm}$ de longitud) fueron distribuidas al azar en unidades experimentales que constaban de tanques circulares de 400 L., con flujo de agua filtrada con un sistema de filtración de esferas Aquadyne ${ }^{\circledR}$ y un esterilizador de luz ultravioleta SmartUV ${ }^{\circledR}$. Fueron utilizados 3 organismos en cada una de las 26 UE.

Bioensayo con licopeno en $\boldsymbol{C}$. auratus. Treinta y seis carpas doradas (37.8 $\pm 10.8 \mathrm{~g}$ de peso $\mathrm{y}$ $134.0 \pm 12.3 \mathrm{~mm}$ de longitud) fueron distribuidos 
described above. One was placed in each of the $36 \mathrm{EU}$.

Bioassay with lycopene in $X$. maculatus. Twenty three platys fish $(0.3 \pm 0.1 \mathrm{~g}$ weight and $26.5 \pm 0.5 \mathrm{~mm}$ length) were distributed randomly in the EU, plastic boxes with $5 \mathrm{~L}$. capacity. Supplementary air was supplied with an electric Boyu $^{\circledR}$ aerator; every third day $100 \%$ of the water was changed to maintain clean water. A fish was placed in each one of the $23 \mathrm{EU}$.

Experimental diets and feeding. In all of the feeding tested in this study grenetina was used at $3 \%(w / w)$ as a binding agent to guarantee the adequate adhesion of the additives.

Bioassay with tomato extract. Goldfish were fed with Nutripec 2506 AP tilapia feed, Purina ${ }^{\circledR}$ brand, extruded, $3.5 \mathrm{~mm}$ length, and $25 \%$ protein. Tomato extract was added to the commercial feed (Lycopersicum esculentum) LICOPENE-100 made by Fórmulas Herbolarias Erick Estrada ${ }^{\circledR}$ in concentrations of $0,1,3$ and $6 \%$ $(\mathrm{w} / \mathrm{w})$. The feed ration was calculated according to $4 \%$ of the initial biomass distributed in two feedings daily (9:00 and 14:00 h)for 45 days.

Bioassay with lycopene in $\boldsymbol{C}$. auratus. The same feeding base was used as in the previous bioassay, adding lycopene made by Essential Nutrition $^{\circledR}$ (50 mg of lycopene in, $75 \mathrm{mg}$ of wheat germ per capsule) in concentrations of 0 , $0.1,0.3$ and $0.6 \%(\mathrm{w} / \mathrm{w})$. The feed ration was calculated according to $4 \%$ of the initial biomass distributed in two daily feedings (9:00 and 14:00 h)for 30 days.

Bioassay with lycopene in X.maculatus. Platys fish were fed with Nutripec $4510 \mathrm{H}$ tilapia feed, Purina ${ }^{\circledR}$ brand, at spawning stage with $45 \%$ protein. The same commercial lycopene in the same concentration was added as described. Feeding was done ad libitum once a day $(9: 00 \mathrm{~h})$ for 60 days.

Experimental design. An initial and final biometry of $100 \%$ of the population was carried out, where the fish were weighed, measured and photographed in order to perceive the effect of the additives on the pigmentation and the parameters: survival, \% weight increase, $\%$ length increase and specific weigh growth increase (9).

For bioassays with $C$. auratus, immediately after the final biometry 4 fish of each treatment were randomly selected and placed in a recipient with room temperature water. For the biotic management of stress in the fish, periodically al azar en UE iguales a las descritas previamente. Se colocó un organismo en cada una de las 36 UE.

Bioensayo con licopeno en $X$. maculatus. Veintitrés peces platys $(0.3 \pm 0.1 \mathrm{~g}$ de peso $\mathrm{y}$ $26.5 \pm 0.5 \mathrm{~mm}$ de longitud) fueron distribuidos al azar en UE constituidas por una caja de material plástico con una capacidad de $5 \mathrm{~L}$. Se suministró aireación suplementaria con un aireador eléctrico marca Boyu ${ }^{\circledR}$, se realizó recambio del $100 \%$ de agua cada tercer día para mantener el agua clara. Se colocó un pez en cada una de las 23 UE.

Dietas experimentales y alimentación. En todos los alimentos probados en este estudio se utilizó grenetina al 3\% (p/p) como aglutinante para garantizar la adhesión adecuada de los aditivos.

Bioensayo con extracto de jitomate. Las carpas doradas fueron alimentadas con un alimento para tilapia Nutripec 2506 AP, marca Purina ${ }^{\circledR}$, extruido, de $3.5 \mathrm{~mm}$ de longitud, y con $25 \%$ de proteína. El alimento comercial fue adicionado con extracto de jitomate (Lycopersicum esculentum) LICOPENO-100 elaborado por Fórmulas Herbolarias Erick Estrada ${ }^{\circledR}$ a concentraciones de 0, 1, 3 y $6 \%$ $(p / p)$. La ración de alimento se calculó de acuerdo con el $4 \%$ de la biomasa inicial repartido en dos tomas diarias (9:00 y 14:00 h), durante 45 días.

Bioensayo con licopeno en C. auratus. Se utilizó el mismo alimento base del bioensayo anterior, se le adicionó LICOPENO elaborado por Essential Nutrition $^{\circledR}$ (50 mg de licopeno en 75 mg de aceite de gérmen de trigo por cápsula) a concentraciones de $0,0.1,0.3$ y $0.6 \%$ (p/p). La ración de alimento se calculó de acuerdo con el $4 \%$ de la biomasa inicial repartido en dos tomas diarias (9:00 y 14:00 h), durante 30 días.

Bioensayo con licopeno en $\boldsymbol{X}$. maculatus. LoS peces platys fueron alimentados con alimento para tilapia Nutripec $4510 \mathrm{H}$, marca Purina ${ }^{\circledR}$, etapa alevinaje con $45 \%$ de proteína. Se le adicionó el mismo licopeno comercial ya descrito en las mismas concentraciones. La alimentación se llevó a cabo ad libitum una vez al día (9:00 h), durante 60 días.

Diseño experimental. Se realizó una biometría inicial y una final del $100 \%$ de la población, en donde los organismos fueron pesados, medidos y fotografiados. Con el fin de conocer el efecto de los aditivos sobre la pigmentación y en los parámetros: sobrevivencia, \% de incremento en peso, \% de incremento en longitud y tasa de crecimiento específico de peso (9).

Para los bioensayos en C. auratus, inmediatamente después de las biometrías finales, se seleccionaron al azar 4 peces de cada tratamiento y se colocaron 
(every 10 minutes) part of the water was substituted with cold water until the fish became lethargic by gradual hypothermia and were finally transferred to a freezer to finish killing them $\left(-20^{\circ} \mathrm{C}, 16 \mathrm{~h}\right)$. In this way the fish showed no evident stress behavior. The fish in the bioassay with tomato extract were cooked, submerged in distilled water for 3 minutes in a microwave, to boiling point; digital photographs were taken before and after cooking to evaluate pigmentation. Fish in the bioassay with lycopene were used to obtain samples of muscle and liver to determine the content of Iycopene.

Determination of antioxidant capacity (CA). The feed in the bioassays of $C$. auratus were performed by the decoloration assay of the ABTS radical, according to the procedure described by Kuskoski et al (10). The initial resulting absorption of the radical ion ABTS was adjusted between $0.72-0.74$ to a wave length of $734 \mathrm{~nm}$ $\left(A_{734}\right)$. After adding $50 \mu \mathrm{L}$ of the extract of the sample to $1000 \mu \mathrm{L}$ of the $\mathrm{ABTS}^{\cdot+}$ solution the $\mathrm{A}_{734}$ was brought to $37^{\circ} \mathrm{C}$ for 6 minutes. The results are expressed in $\mu \mathrm{mol}$ equivalents to Trolox $/ \mathrm{g}$.

Lycopene determination. The bioassay with lycopene in $C$. auratus was done according to the method described by Fish et al (11) in the feed, as well as in the liver and muscles of the fish.

Pigmentation evaluation. The analysis of photographs was done with Photoshop ${ }^{\circledR}$ for specific regions of the body, according to the method described by Yasir et al (12). In $C$. auratus the cephalic, toracic and caudal fin region was analyzed; in $X$. maculatus the body, peduncle caudal and caudal fin. Values were obtained with the HSB model (Hue, Saturation and Brightness) to obtain possible changes in coloring.

Statistical analysis of data. The results obtained in this study were expressed as a measure of the values with their corresponding standard deviations. The results presented as percentages were transformed with a square root function of the Arcsine (13). Data from one experiment was statistically compared using the one way variation analysis (ANOVA) after normality tests (Kolmogorov-Smirnov; $a=0.05$ ) and homocedasticidad (Bartlett; $a=0.05$ ). The differences were considered statistically significant when $p<0.05$. The differences being statistically significant from the ANOVA, the differences between measurements were compared by means of the multiple measurements comparation test of Tukey. The data was analyzed with the SigmaStat V 3.1 statistics program (2004) (9). en un recipiente con agua a temperatura ambiente. Para un manejo biótico del estrés de los organismos, periódicamente (cada 10 minutos) se sustituyó parte del agua por agua fría hasta que los organismos se aletargaron por la hipotermia gradual, finalmente se transfirieron a un congelador para terminar el sacrificio de los mismos $\left(-20^{\circ} \mathrm{C}, 16 \mathrm{~h}\right)$. De esta manera los peces no presentaron un comportamiento de estrés evidente. Los peces del bioensayo con extracto de jitomate se sometieron a un proceso de cocción, sumergidos en agua destilada durante 3 minutos en horno de microondas, alcanzando el punto de ebullición; se les tomaron fotografías digitales antes y después de la cocción para evaluar la pigmentación. Los peces del bioensayo con licopeno se utilizaron para obtener muestras de músculo e hígado para determinar el contenido de licopeno.

Determinación de capacidad antioxidante (CA). En los alimentos de los bioensayos en $C$. auratus se realizó por el ensayo de decoloración del radical ABTS, según el procedimiento descrito por Kuskoski et al (10). La absorbancia inicial del ión radical ABTS resultante fue ajustada entre 0.72-0.74 a una longitud de onda de 734 $\mathrm{nm}\left(\mathrm{A}_{734}\right)$. Tras añadir $50 \mu \mathrm{L}$ del extracto de la muestra a $1000 \mu \mathrm{L}$ de la solución $\mathrm{ABTS}^{\bullet+}$ se determinó la $A_{734}$ a $37^{\circ} \mathrm{C}$ durante 6 minutos. Los resultados se expresan en $\mu \mathrm{mol}$ equivalentes de Trolox/g.

Determinación de licopeno. Para el bioensayo con licopeno en $C$. auratus se realizó según el método descrito por Fish et al (11) en los alimentos, así como en el hígado y músculo de los peces.

Evaluación de la pigmentación. Se realizó el análisis de las fotografías con el programa Photoshop ${ }^{\circledR}$ en regiones específicas del cuerpo, según el método descrito por Yasir et al (12). En C. auratus se analizó la región cefálica, torácica y aleta caudal; en $X$. maculatus se analizó el cuerpo, pedúnculo caudal y aleta caudal. Se utilizaron los valores obtenidos por el modelo HSB (por sus siglas en inglés: Hue [matiz], Saturation [cantidad de color] y Brightness [brillo]) para obtener los posibles cambios en la coloración.

Análisis estadístico de los datos. Los resultados obtenidos en este estudio se expresaron como media de los valores con sus correspondientes desviaciones estándar. Los resultados que se presentaron como porcentajes fueron transformados con la función raíz cuadrada del Arcoseno (13). Los datos de un mismo experimento se compararon estadísticamente utilizando el análisis de varianza de una vía (ANOVA) previas pruebas de normalidad (Kolmogorov-Smirnov; $a=0.05$ ) y homocedasticidad (Bartlett; $a=0.05$ ). 


\section{RESULTS}

The level of inclusion of tomato extract and comercial lycopene did not influence the growth of $C$. auratus (Table 1 ), since no significant differences were found ( $p>0.05)$ among the treatments, including the control group, in each one of the bioassays.

Table 1. Growth of fish in bioassays with C. auratus.

\begin{tabular}{|c|c|c|c|c|}
\hline \multicolumn{5}{|c|}{ Bioassay with tomato extract } \\
\hline & Control & $\begin{array}{c}1 \% \\
(p / p)\end{array}$ & $\begin{array}{c}3 \% \\
(p / p)\end{array}$ & $\begin{array}{c}6 \% \\
(p / p)\end{array}$ \\
\hline \multirow{2}{*}{ Survival (\%) } & 94.4 & 100 & 100 & 95.2 \\
\hline & \pm 0.5 & \pm 0.0 & \pm 0.0 & \pm 0.7 \\
\hline \multirow{2}{*}{ Increase in weight (\%) } & 56.1 & 42.3 & 37.5 & 45.2 \\
\hline & \pm 12.4 & \pm 19.2 & \pm 7.3 & \pm 15.3 \\
\hline \multirow{2}{*}{ Increase in size $(\%)$} & 11.7 & 10.6 & 9.9 & 12.4 \\
\hline & \pm 3.1 & \pm 2.3 & \pm 1.9 & \pm 3.8 \\
\hline TCE & $\begin{array}{c}1.0 \\
\pm 0.2\end{array}$ & $\begin{array}{c}0.8 \\
\pm 0.3 \\
\end{array}$ & $\begin{array}{c}0.7 \\
\pm 0.1\end{array}$ & $\begin{array}{c}0.8 \\
\pm 0.2\end{array}$ \\
\hline \multicolumn{5}{|c|}{ Bioassay with lycopene } \\
\hline & Control & $\begin{array}{l}0.1 \% \\
(p / p)\end{array}$ & $\begin{array}{l}0.3 \% \\
(p / p)\end{array}$ & $\begin{array}{l}0.6 \% \\
(p / p)\end{array}$ \\
\hline \multirow[t]{2}{*}{ Survival (\%) } & 100 & 100 & 100 & 100 \\
\hline & \pm 0.0 & \pm 0.0 & \pm 0.0 & \pm 0.0 \\
\hline \multirow{2}{*}{ Increase in weight $(\%)$} & 22.2 & 23.9 & 21.6 & 24.1 \\
\hline & \pm 13.0 & \pm 21.4 & \pm 12.1 & \pm 12.3 \\
\hline Increase in size (\%) & $\begin{array}{c}7.9 \\
\pm 5.8\end{array}$ & $\begin{array}{c}6.5 \\
\pm 3.5\end{array}$ & $\begin{array}{c}8.7 \\
\pm 3.8\end{array}$ & $\begin{array}{c}9.2 \\
\pm 4.2\end{array}$ \\
\hline TCE & $\begin{array}{c}0.6 \\
+0.4\end{array}$ & 0.7 & 0.6 & $\begin{array}{l}0.7 \\
+0.3\end{array}$ \\
\hline
\end{tabular}

In the ABTS analysis of the $C$. auratus bioassays, no significant differences could be found $(p>0.05)$ between the control and the feed with the tomato extract, but significant differences were found $(p<0.05)$ in the feed with added lycopene, the control had lessened antioxidant capacity than the experimental feed (Table 2).

In determining the lycopene in experimental feed and the bioassay fish with lycopene in $C$. auratus (Table 3 ) significant differences were found $(p<0.05)$, fish fed with the $0.6 \%$ treatment $(w / w)$ had a greater capacity of accumulated lycopene in the liver.

The results of the analysis of the pigmentation were found in figures 1,2 and 3 . No significant effects $(p>0.05)$ were found in the increase in pigmentation by means of the HSB analysis in

Table 3. Lycopene content in experimental feed, as well as in liver and muscle of fish fed with it.

\begin{tabular}{|c|c|c|c|}
\hline \multirow{3}{*}{ Treatment } & \multicolumn{3}{|c|}{ Lycopene Content } \\
\hline & \multicolumn{3}{|c|}{ ( $\mu$ g lycopene/kg) } \\
\hline & Feed & Liver & Muscle \\
\hline Control & $1.9 \pm 0.2^{c}$ & $3.1 \pm 0.9^{b}$ & $4.4 \pm 1.0^{b}$ \\
\hline $0.1 \%(w / w)$ & $2.6 \pm 0.1^{b}$ & $3.9 \pm 0.6^{b}$ & $6.8 \pm 2.3 \mathrm{ab}$ \\
\hline $0.3 \%(w / w)$ & $2.9 \pm 02 \mathrm{ab}$ & $3.1 \pm 1.1^{b}$ & $7.8 \pm 1.1$ ab \\
\hline $0.6 \%(w / w)$ & $3.2 \pm 0.1^{a}$ & $10.0 \pm 1.6^{a}$ & $10.1 \pm 2.3^{a}$ \\
\hline
\end{tabular}

Different superscripts per bioassay show statistically significant differences between treatments $(p<0.05)$.
Las diferencias fueron consideradas estadísticamente significativas cuando $p<0.05$. Detectadas las diferencias estadísticamente significativas con el ANOVA, las diferencias entre medias fueron comparadas mediante el test de comparación múltiple de medias de Tukey. Los datos se analizaron con el programa estadístico SigmaStat V 3.1 (2004) (9).

\section{RESULTADOS}

El nivel de inclusión de extracto de jitomate y de licopeno comercial no influyó en el crecimiento de los peces $C$. auratus (Tabla 1 ), ya que no se encontraron diferencias significativas $(p>0.05)$ entre los tratamientos, incluyendo el control, de cada uno de los bioensayos.

En el análisis ABTS en los bioensayos en $C$. auratus, no se obtuvieron diferencias significativas $(p>0.05)$ entre el control y los alimentos adicionados con el extracto de jitomate, pero si se obtuvieron diferencias significativas $(p<0.05)$ en los alimentos adicionados con licopeno, obteniendo el control menor capacidad antioxidante que los alimentos experimentales (Tabla 2).

Table 2. Antioxidant activity in administered diets, as well as in the tomato extract used.

\begin{tabular}{lcc}
\hline \multicolumn{1}{c}{ Sample } & \multicolumn{1}{c}{ CA $(\boldsymbol{\mu}$ M of Trolox $/ \mathbf{g})$} \\
\hline Tomato extract & Control & $9.4 \pm 0.2^{\mathrm{a}}$ \\
& $1 \%(\mathrm{w} / \mathrm{w})$ & $8.7 \pm 0.2^{\mathrm{a}}$ \\
Bioassay with tomato extract & $3 \%(\mathrm{w} / \mathrm{w})$ & $9.0 \pm 0.1^{\mathrm{a}}$ \\
& $6 \%(\mathrm{w} / \mathrm{w})$ & $9.2 \pm 0.3^{\mathrm{a}}$ \\
& Control & $9.4 \pm 0.2^{\mathrm{c}}$ \\
Bioassay with lycopene & $0.1 \%(\mathrm{w} / \mathrm{w})$ & $17.8 \pm 0.1^{\mathrm{b}}$ \\
& $0.3 \%(\mathrm{w} / \mathrm{w})$ & $19.8 \pm 0.3^{\mathrm{a}}$ \\
& $0.6 \%(\mathrm{w} / \mathrm{w})$ & $19.4 \pm 0.6^{\mathrm{a}}$ \\
\hline
\end{tabular}

Different superscripts per bioassay show statistically significant differences $(p<0.05)$.

En la determinación de licopeno en los alimentos experimentales y de los peces del bioensayo con licopeno en $C$. auratus (Tabla 3 ) se encontraron diferencias significativas $(p<0.05)$, los peces alimentados con el tratamiento de $0.6 \%(\mathrm{p} / \mathrm{p})$ tuvieron mayor cantidad de licopeno acumulado en el hígado.

Los resultados del análisis de la pigmentación se muestran en las figuras 1,2 y 3 . No se encontró efecto significativo $(p>0.05)$ en el incremento de la pigmentación, a través del análisis HSB, en ninguna de las regiones analizadas de los peces sometidos a los alimentos experimentales en ninguno de los tres bioensayos. 

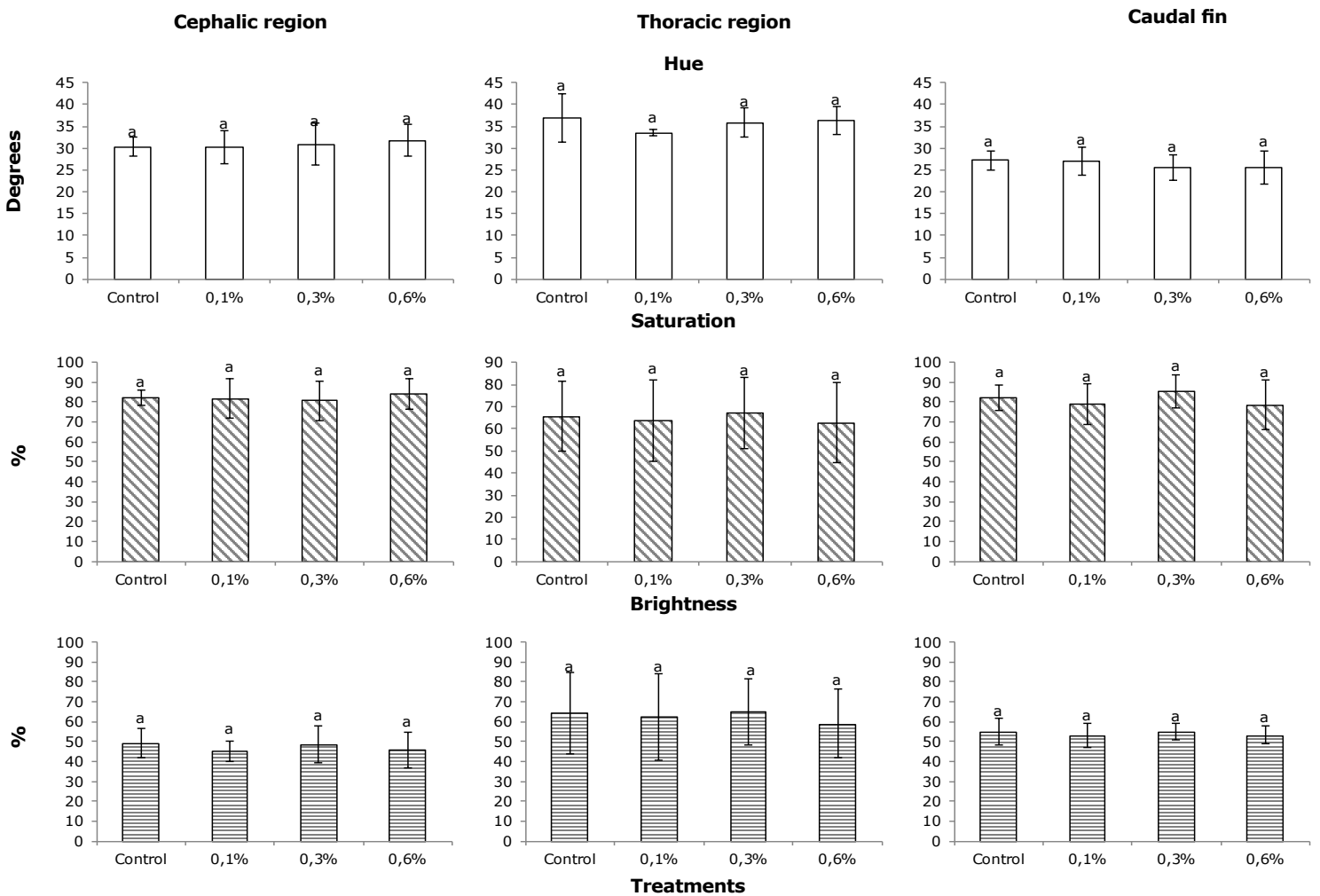

Figure 1. Results of color analysis (HSB) in bioassay with tomato extract in C. auratus.
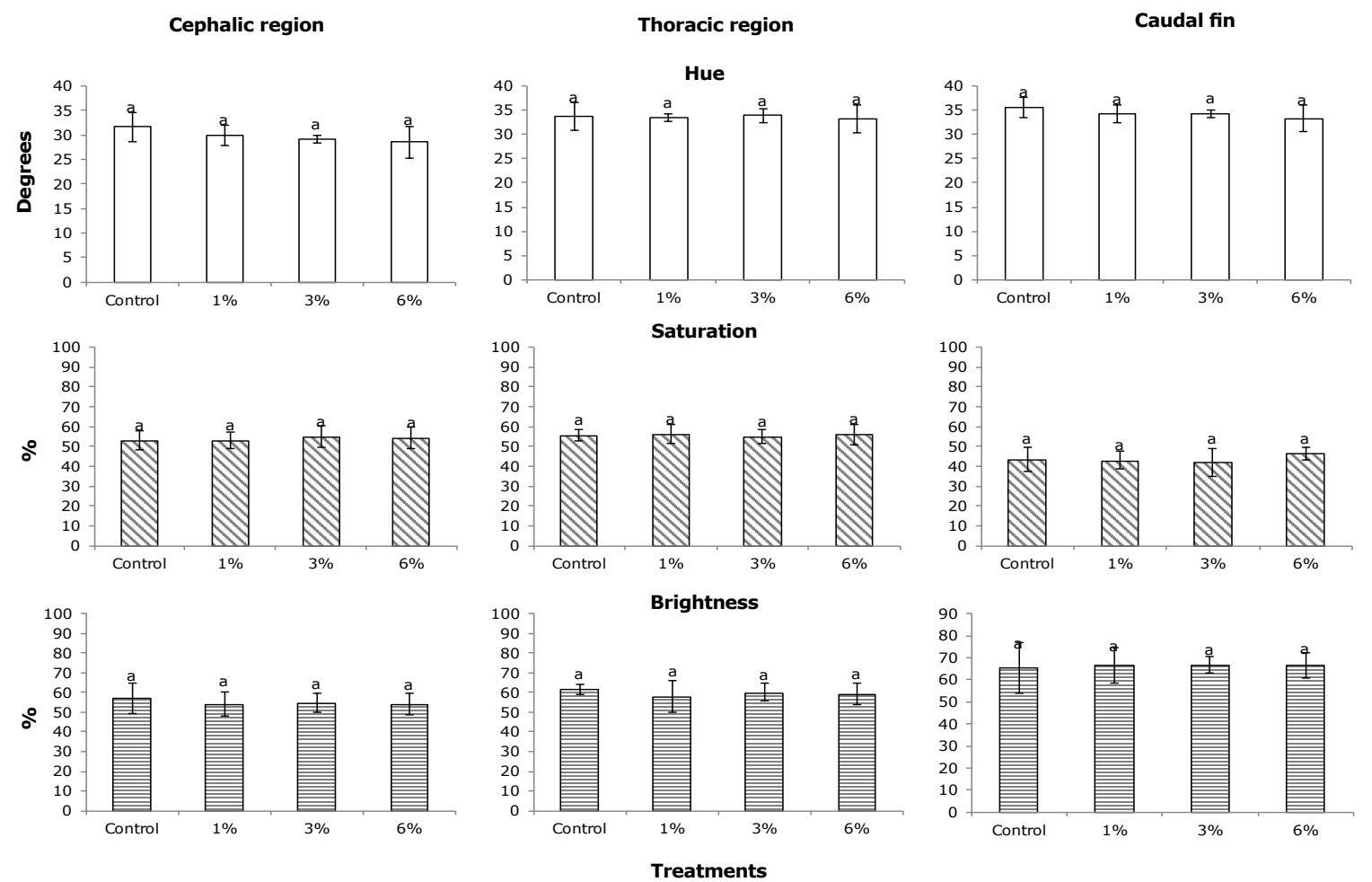

Figure 2. Results of color analysis (HSB) in bioassay with lycopene in C. auratus. 

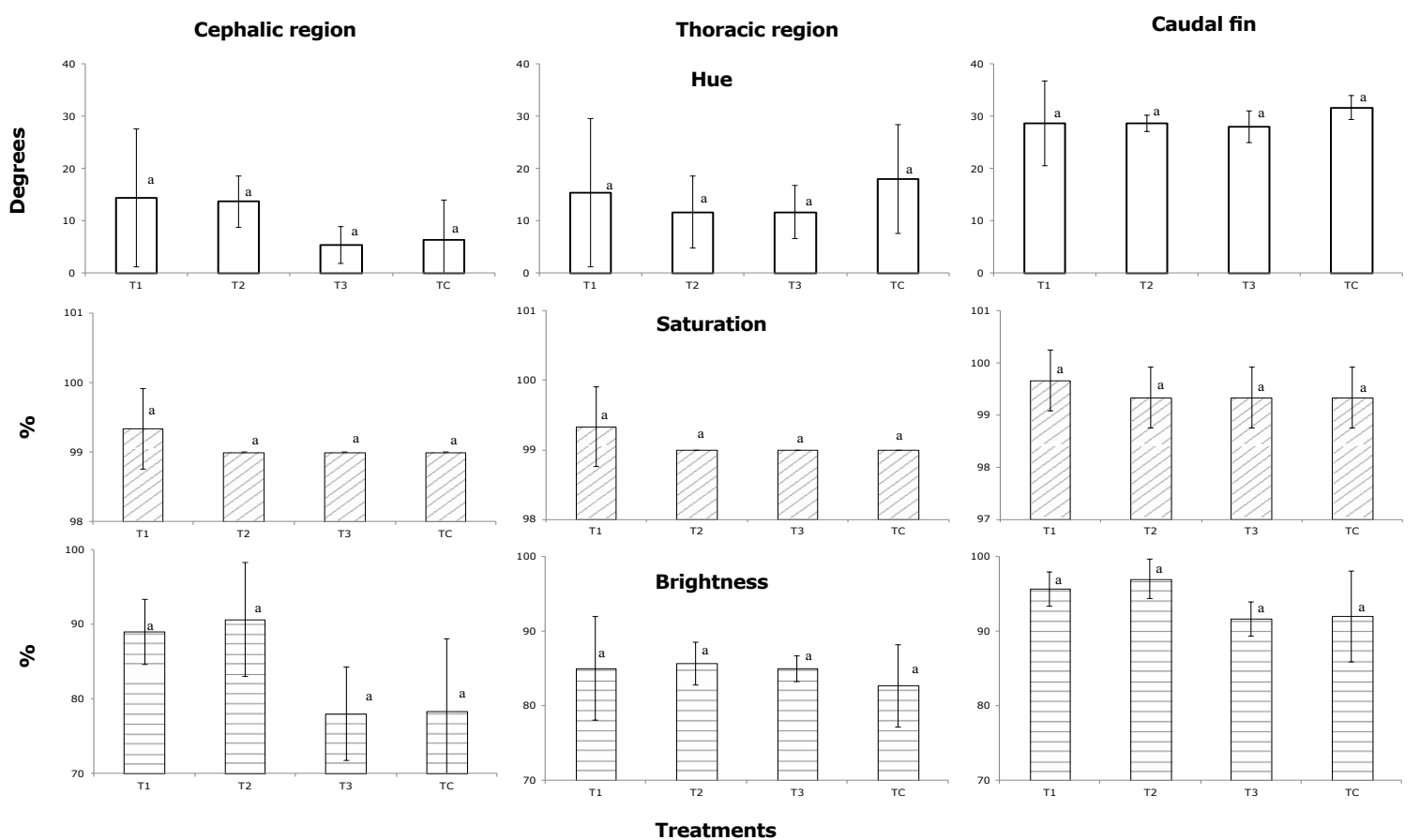

Treatments

Figure 3. Results of color analysis (HSB) in bioassay with lycopene in $X$. maculatus.

any of the regions analyzed of the fish fed the experimental feed in any of the three bioassays.

The red color of crustaceans is produced by carotenoid of the carotene-protein when it is denaturalized by cooking (14) so that this complex can affect the capacity to absorb light of the carotenoide molecule.

The analysis results of the pigmentation of raw and cooked fish in the bioassay with tomato extract in $C$. auratus is shown in figure 4 . Significant differences $(p>0.05)$ in the hue between treatments of the cooked fish are shown, but all treatments are the same as the control group, and therefore it could not be demonstrated that a connection exists between the supplied lycopene in diets with proteins in the tegument of the fish.
El color rojo de los crustáceos se produce por la liberación del carotenoide del complejo carotenoproteínas cuando es desnaturalizado por el calor de cocción (14), por lo que este complejo puede afectar la capacidad de absorción de luz de la molécula del carotenoide.

Los resultados del análisis de la pigmentación de los peces crudos y cocidos del bioensayo con extracto de jitomate en $C$. auratus se muestran en la figura 4. Se encontraron diferencias significativas $(p>0.05)$ en el matiz entre tratamientos dentro de los peces cocidos, pero todos los tratamientos son iguales al control, por lo que no se pudo demostrar que exista una asociación del licopeno suministrado en las dietas con las proteínas en el tegumento de los peces.
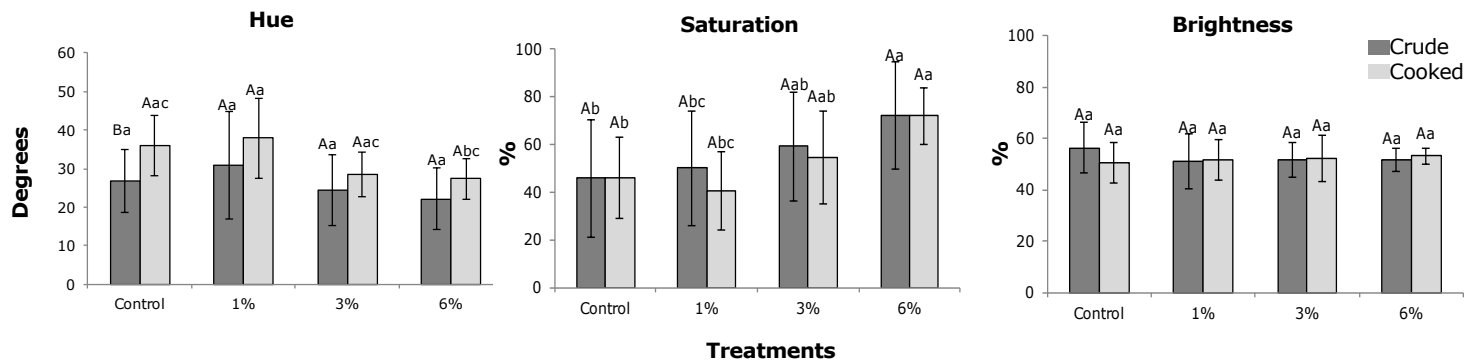

Figure 4. Results of color analysis (HSB) of the bioassay with tomato extract in fish subject to cooking. The vertical lines in each bar represent the standard deviation for each treatment. Different superscripts in capitals indicate statistically significant differences $(p<0.05)$ between the presentation (raw and cooked) within each treatment. Superscripts in lower case indicate statistically significant differences $(p<0.05)$ between treatment within each presentation(raw and cooked). 


\section{DISCUSSION}

This study confirms that carotenoids do not play an important role in the growth of goldfish. Although these results agree with some studies, for example, $\mathrm{Xu}$ et al (2) reported that adding astaxanthin to red yeast (Xanthophyllomyces dendrorhous) did not have any effect on the weight gain in goldfish. Gouveia et al (15) performed two assays in the ornamental species of the goldfish (Carassius auratus) being fed a dietary supplement of carotenoids of the biomass of microalgae sweet water [Chlorella vulgaris, Haematococcus pluvialis, and cianobacteria Arthrospira maxima (Spirulina)], using a diet containing synthetic astaxanthin and a control diet, without coloring, for comparison, and it was found that feeding growth and efficiency were not significantly different among the groups with the different dietary treatments. The results of Yeşilayer et al (16) were similar, where young goldfish were fed five different diets: astaxanthin, canthaxanthin, Gammarus spp., paprika and a control group without supplement; it was found that growth and the feeding conversion index were not different from the control group in the groups fed with carotenoids.

Not all studies showed similar results: Kiriratnikom et al (3) reported that spirulina induces growth and color of goldfish; they found greater growth with a diet of $3 \%(p / p)$ of dried spirulina. Anhilan et al (17) in $C$. auratus (linnaeus) fed with botanical additives such as coriander, mint and amaranth as a source of carotenoids obtained better weight gain using amaranth at $1 \%(\mathrm{w} / \mathrm{w})$, followed by fish fed by coriander at $3 \%(w / w)$. Wallat et al (18) used six different commercial diets supplemented with different carotenoids and showed they have a variable effect on skin color and the growth of juveniles of Oranda of C. auratus. Moreira et al (19) reported that in feeding treatments with Artemia and comercial feed in flakes in a circulation system and another with a static system, they found significant differences in growth (weight and size) in animals fed with Artemia (at 60 days). Also, they mentioned that the animals that received Artemia had improved pigmentation, although they did not offer any data on this last point.

The antioxidant capacity of experimental feed determined by the ABTS method has shown its increase in feed with added lycopene, but it could not be concluded that tomato extract does not increase the antioxidant capacity in the diets, since due to the complexity of the oxidation processes it is obvious that no one method of testing exists that completely reflects the antioxidant profile of the studied samples (20).

\section{DISCUSIÓN}

El presente trabajo confirma que los carotenoides no juegan un papel importante en el crecimiento de las carpas doradas. Aunque estos resultados están de acuerdo con algunos estudios realizados, por ejemplo, Xu et al (2) reportaron que la adición de astaxantina de la levadura roja (Xanthophyllomyces dendrorhous) no tuvo ningún efecto sobre la ganancia de peso en carpas doradas. Gouveia et al (15) realizaron dos ensayos en las especies ornamentales entre ellos la carpa dorada (Carassius auratus) con la alimentación de un suplemento dietético de carotenoides de la biomasa de microalgas de agua dulce [Chlorella vulgaris, Haematococcus pluvialis, y cianobacteria Arthrospira maxima (Spirulina)], utilizando una dieta que contiene astaxantina sintética y una dieta control, sin colorante, para la comparación y se encontró que el crecimiento y la eficiencia alimenticia no fueron significativamente diferentes entre los grupos administrados por los diferentes tratamientos dietéticos. Similar a los resultados de Yeşilayer et al (16) en donde juveniles de carpas doradas fueron alimentadas con cinco diferentes dietas: astaxantina, cantaxantina, Gammarus spp., paprika y un control sin suplemento; encontraron que el crecimiento y el índice de conversión alimenticia no difirió del control con los grupos alimentados con carotenoides.

No todos los estudios obtuvieron resultados similares: Kiriratnikom et al (3) reportaron que la espirulina induce el crecimiento y el color de la carpa dorada; encontrando el mayor crecimiento con la dieta introducida al $3 \%(\mathrm{p} / \mathrm{p})$ de espirulina seca. Anhilan et al (17) en C. auratus (linnaeus) alimentados con aditivos botánico como cilantro, menta y amaranto como fuente de carotenoides, obteniendo la mayor ganancia de peso utilizando amaranto al $1 \%(\mathrm{p} / \mathrm{p})$, seguido por los peces alimentados con cilantro al 3\% ( $p / p)$. Wallat et al (18) utilizaron seis dietas comerciales diferentes suplementadas con diferentes carotenoides y demostraron que tienen un efecto muy variable en la coloración de la piel y el crecimiento de juveniles de la variedad de Oranda de $C$. auratus. Moreira et al (19) reportan que bajo tratamientos alimenticios con Artemia y alimento comercial en hojuelas y bajo un sistema de recirculación y otro estático, encontraron diferencias significativas en crecimiento (peso y talla) en los animales alimentados con Artemia (a los 60 días). También, mencionan que los organismos que recibieron Artemia incrementaron su pigmentación, aunque no ofrecen dato alguno sobre esto último.

La capacidad antioxidante de los alimentos experimentales determinada por el método ABTS 
Additionally, the antioxidant capacity of a mix is not just the sum of the antioxidant capacities of each one of its components; it also depends on the microenvironment in which it is found; the compounds interact with each other, which can produce synergic or inhibitor effects (10). Consideration should be given to the fact that the majority of the studies done that have been referred to consider the antioxidant activity of the additives or ingredients used, but generally do not evaluate the antioxidant effect of the diet as a whole.

Anhilan et al (17) comment that some investigators found that the development of color seems to depend on the quantity and nature of the carotenoid present in the source of the pigment/ingredient. This is confirmed by the present investigation, since no improvement was found in color when lycopene was used as a carotenoid, contrary to what was found in the majority of the studies that have evaluated the pigmentation of $C$. auratus with different natural sources of carotenoids and have shown to be an alternative to increase the pigmentation in these fish. In their investigation, Yanar et al (4) found that the addition of $15 \%$ alfalfa to the diet can guarantee good pigmentation and acceptable growth when used in goldfish.

Also, Gouveia et al (15) reported that microalgae (Chlorella vulgaris, Haematococcus pluvialis and Arthrospira máxima(Spirulina)) added as carotenoid to the diet increased the content of total carotenoids in the skin of goldfish and that good color was obtained using $C$. vulgaris and the best red color was obtained using $H$. pluvialis. Kiriratnikom et al (3) reported that the results of their investigation showed the positive effect of dried spirulina in the pigmentation of goldfish. $\mathrm{Xu}$ et al (2), when evaluating the addition of astaxanthin to red yeast (Xanthophyllomyces dendrorhous) in the diet of $C$. auratus, obtained an improvement in color; carotenoid deposits in fish fed with supplemented diets was significantly increased after the $15^{\text {th }}$ day of feeding in comparison with fish fed with a diet without astaxanthin, but the effect on the color of the fish was evident on the $60^{\text {th }}$ day. Sinha et al (21) made a similar observation in their study with Hibiscus rosasinensis petals, where they showed that it is a powerful natural source of carotenoids in $C$. auratus that improves their color as well as accelerates gonad development and growth.

Anhilan et al (17) confirmed that the percentage of color development was greater in fish fed with coriander than with amaranth and mint; this could be directly attributed to the higher level of carotenoid content. Orbe-Rogel (22) proved ha puesto de manifiesto el incremento de la misma en los alimentos adicionados con licopeno, pero no se podría concluir que el extracto de jitomate no incrementa la capacidad antioxidante en las dietas, ya que debido a la complejidad de los procesos de oxidación es obvio que no existe un único método de prueba que refleje de forma completa el perfil antioxidante de la muestra estudiada (20). Además, la capacidad antioxidante de una mezcla no viene dada solo por la suma de las capacidades antioxidantes de cada uno de sus componentes, también, depende del microambiente en que se encuentra; los compuestos interactúan entre sí pudiendo producirse efectos sinérgicos o inhibitorios (10). Debe considerarse que la mayoría de los estudios realizados, referidos previamente, consideran la actividad antioxidante de los aditivos o ingredientes utilizados, pero generalmente no evalúan el poder antioxidante de la dieta completa.

Anhilan et al (17) comentan que algunos investigadores encontraron que el desarrollo del color pareciera depender de la cantidad y de la naturaleza del carotenoide presente en la fuente de pigmento/ingrediente. Esto es confirmado en la presente investigación al no haber encontrado mejoras en la coloración al utilizar como carotenoide el licopeno, caso contrario a lo que se confirmó en la mayoría de los trabajos que han evaluado la pigmentación de C. auratus, con diferentes fuentes naturales de carotenoides y han demostrado ser una alternativa para incrementar la pigmentación de estos peces. Yanar et al (4) en su investigación obtuvieron que la adición del $15 \%$ de alfalfa en la dieta puede garantizar una buena pigmentación y crecimiento aceptable en su utilización en carpa dorada.

También Gouveia et al (15) reportaron que añadir microalgas (Chlorella vulgaris, Haematococcus pluvialis y Arthrospira máxima (Espirulina)) como carotenoides en la dieta, se aumenta el contenido de carotenoides totales en la piel de carpa dorada y que el mejor color obtenido se logró utilizando C. vulgaris y el máximo color rojo cuando se utilizó $H$. pluvialis. Kiriratnikom et al (3) reportaron que los resultados de su investigación mostraron un efecto positivo de espirulina seca en la pigmentación de carpa dorada. Xu et al (2) al evaluar la adición de astaxantina de la levadura roja (Xanthophyllomyces dendrorhous) en las dietas de $C$. auratus, obtuvieron una mejora de color; la deposición de carotenoides en los peces alimentados con las dietas suplementadas se incrementó significativamente después del día 15 de alimentación en comparación con la de los peces alimentados con la dieta sin astaxantina, pero el efecto sobre el color en los peces fue 
that adding carotenoids in the flower of petals of cempaxúchil presented effects in the growth rate and improved the pigmentation of the skin, although the high concentrations have a negative effect on the pigmentation of goldfish. Yeşilayer et al (16) demonstrated that paprika was as effective as a source of carotenoids as synthetic cantaxanthin and astaxanthin. The results indicated that the $C$. auratus fish were capable of using in an efficient manner the capsanthin paprika. Pérez-Escalante (23) observed that the food added with the pigments of ground Hibiscus flower can be used as an alternative source to the natural pigments to color $C$. auratus, as well as improving their growth.

Few studies have been done to evaluate lycopene as a compound with a pigmenting capacity in fish. Chatzifotis et al (1) reported that lycopene did not have significant effects on coloring the skin of red porgy (Pagrus pagrus); these results are in agreement with this study, where no significant effect on the pigmentation of $C$. auratus and $X$. maculates fish were found.

Carotenoids are synthesized by photosynthetic and carotenogenic organisms, the conversion of different carotenoids are catalyzed by enzymes $(24,25)$. The primary red or carotenoid pigment in the skin of goldfish was identified as astaxanthin. Contradictory reports in literature exist about the capacity of goldfish to metabolize other carotenoid pigments in astaxanthin. Wallat et al (18), citing Hata et al (26), reported on the poor conversión of lutein and $\beta$-caroteno to astaxanth in goldfish, which is capable of metabolizing equinone to cantaxanthin but can barely metabolize $\beta$-carotene to equinone, suggesting that these results show the lack of enzyme in the first stage (Figure 5), which should be investigated in future studies.

Concerning lycopene, no investigation was found that could be used as a base to suggest the reason why fish used in this study could not incorporate pigments in their tegument from the lycopene.

With these results, it is proposed that fish show the capacity to absorb lycopene in the enterocytes of the intestinal wall, since it was found accumulated in muscles and liver in the treatment where they were fed at an inclusion level of $0.6 \%$. This is congruent since the liver is the principal metabolic organ and excreter of carotenoids (27); however, it seems that this storage does not imply that the metabolisms of fish can achieved astaxanthin. The carotenoids were not found as complex carotene-protein in the tegument of the fish, as happens in evidente hasta el día 60 . Observación similar hizo Sinha et al (21) en su estudio con pétalos de Hibiscus rosasinensis, donde mostraron que es una potente fuente natural de carotenoides en $C$. auratus para mejorar su color, asi como también para acelerar su desarrollo gonadal y su crecimiento.

Anhilan et al (17) confirmaron que el porcentaje de desarrollo del color fue mayor en los peces alimentados con cilantro, que con el amaranto y la menta; esto se podría atribuir directamente a su nivel más alto de contenido de carotenoides. Orbe-Rogel (22) comprobó que la adición de carotenoides de la harina de pétalos de cempaxúchil presentó efectos en la tasa de crecimiento y potenció la pigmentación de la piel, aunque a concentraciones altas tiene un efecto negativo en la pigmentación de las carpas doradas. Yeşilayer et al (16) demostraron que la paprika fue tan eficaz como una fuente de carotenoides de cantaxantina y astaxantina sintética. Los resultados indicaron que los peces $C$. auratus fueron capaces de utilizar de manera eficiente la capsantina de la paprika. Pérez-Escalante (23) observó que los alimentos adicionados con los pigmentos de la harina de la flor de Jamaica, puede ser utilizada como fuente alternativa de los pigmentos naturales para proporcionar color a $C$. auratus, mejorando además su crecimiento.

A saber pocos estudios se han realizado evaluando al licopeno como compuesto con capacidad pigmentante en peces. Chatzifotis et al (1) reportan que el licopeno no tuvo ningún efecto significativo sobre la coloración de la piel del besugo (Pagrus pagrus); estos resultados concuerdan con los de este estudio donde no se obtuvo ningún efecto significativo en la pigmentación de los peces $C$. auratus y $X$. maculatus.

Los carotenoides son sintetizados por organismos fotosintéticos y carotenogénicos, las conversiones de los diferentes carotenoides son catalizadas por enzimas $(24,25)$. El pigmento primario rojo o carotenoide en la piel de las carpas doradas se identificó como astaxantina. Existen informes contradictorios en la literatura sobre la capacidad de las carpas doradas para metabolizar otros pigmentos carotenoides en astaxantina. Wallat et al (18), citando a Hata et al (26), reportan la conversión pobre de luteína y $\beta$-caroteno a astaxantina en carpa dorada, la cual es capaz de metabolizar la equinona a cantaxantina pero apenas pueden metabolizar el $\beta$-caroteno a equinona, por lo que estos resultados sugieren la falta de la enzima de la primer etapa (Figura 5) lo cual debe ser investigado en próximos estudios. 


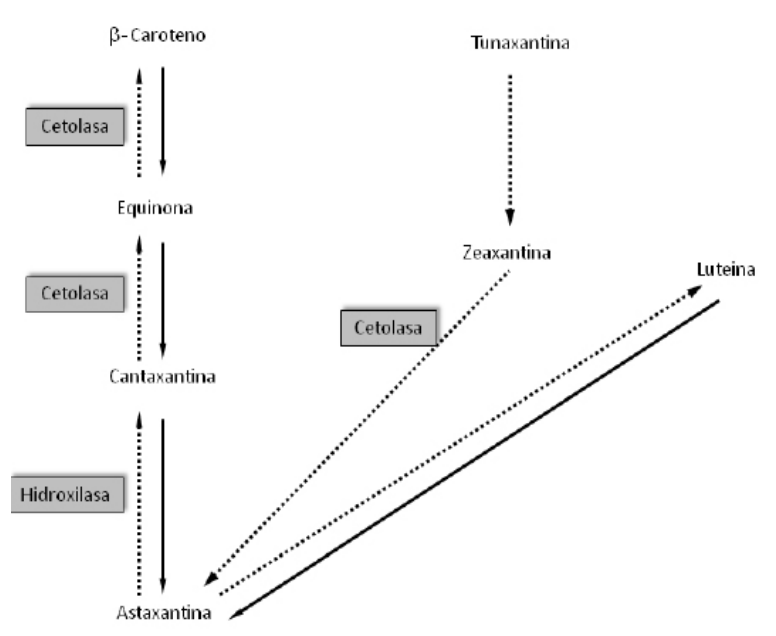

Figura 5. Hypothetical metabolic pathways of carotenoids in fish. Modified from (26).

invertebrate marine organisms, and that can affect the capacity of light absorption of the carotenoid molecule.

The results obtained suggest that the inability of lycopene to increase color in these fish can be due to the lack of an enzymatic system that transforms it into $\beta$-carotene and to astaxanthin, probably due to the lack of $\beta$-ciclase (25); however, this should be proved.

Based on the results of this investigation, it can be concluded that it is not recommended to include the extract of tomato or of lycopene in feed for Carassius auratus or for Xiphophorus maculatus in order to improve pigmentation and growth, although other studies are required to demonstrate the antioxidant effect in fish and its contribution to health improvement.

\section{Acknowledgements}

To Dr. José Luis Rodríguez of the Cuba Ministry of Food Industry. To M.C. Olimpia Chong Carrillo for providing information.
Sobre el licopeno no se encontró investigación alguna que pudiera servir como fundamento para sugerir la razón por la cual los peces utilizados en este estudio no pudieron incorporar pigmentos en su tegumento a partir del licopeno.

Con estos resultados, se propone que los peces muestran la capacidad de absorber licopeno en los enterocitos de la pared intestinal, ya que se encontró acumulado en el músculo y en el hígado en el tratamiento en donde se alimentó con un nivel de inclusión del $0.6 \%$. Esto es congruente ya que el hígado es el principal órgano metabólico y excretor de los carotenoides (27); sin embargo, al parecer este almacenamiento no implica que el metabolismo del pez lo pueda llevar hasta astaxantina. Los carotenoides tampoco se encontraron como complejos de carotenoproteínas en el tegumento de los peces, como sucede en organismos marinos invertebrados y que pudieran estar afectando la capacidad de absorción de luz por la molécula del carotenoide.

Los resultados obtenidos sugieren que la incapacidad del licopeno de incrementar el color en estos peces puede originarse en la falta de un sistema enzimático que permita su transformación a $\beta$-caroteno y a partir de este a astaxantina, probablemente por la falta de $\beta$-ciclasa (25), sin embargo, esto debe ser comprobado.

Basados en los resultados de esta investigación, se puede concluir que no es recomendable la inclusión de extracto de jitomate o de licopeno en alimentos para Carassius auratus o para Xiphophorus maculatus, con el fin de mejorar la pigmentación y el crecimiento, aunque se requieren otros estudios para demostrar su efecto antioxidante en los peces y que pudiera contribuir a mejorar el estado de salud de los mismos.

\section{Agradecimientos}

Al Dr. José Luis Rodríguez del Ministerio de la Industria Alimenticia de Cuba. A la M.C. Olimpia Chong Carrillo por la gestión de información.

\section{REFERENCES}

1. Chatzifotis S, Pavlidis M, Doñate-Jimeno C, Vardanis G, Stereoti A, Divanach P. The effect of different carotenoid sources on skin coloration of cultured red porgy (Pagrus pagrus). Aquac Res 2005; 36(15):1517-1525.

2. Xu X, Jin Z, Wang $H$, Chen $X$, Wang $C$, Yu W. Effect of astaxanthin from Xanthophyllomyces dendrorhous on pigmentation of goldfish, Carassius auratus. J World Aquacult Soc 2006; 37:282-288.
3. Kiriratnikom S, Zaau R, Suwanpugdee A. Effects of various levels of Spirulina on growth performance and pigmentation in goldfish (Carassius auratus). Songklanakarin J Sci Technol 2005; 27:133-139.

4. Yanar M, Erçen Z, Özlüer HA, Büyükçapar HM. The use of alfalfa, Medicago sativa as a natural carotenoid source in diets of goldfish, Carassius auratus. Aquaculture 2008; 284(1-4):196-200. 
5. Guillaume J, Kaushik S, Bergot P, Metailler R. Nutrición y alimentación de peces y crustáceos. España: Ed. Mundi-prensa; 2004.

6. Cardona EM, Ríos LA, Restrepo GM. Extracción del carotenoide licopeno del tomate Chonto (Lycopersicum esculentum). Vitae 2006; 13(2):44-53.

7. Waliszewski KN, Blasco G. Propiedades nutraceúticas del licopeno. Salud pública Méx 2010; 52(3):254-265.

8. Roberfroid MB. Global view on functional foods: European perspectives. Br J Nutr 2002; 88(Supl 2):S133-S138.

9. Vega-Villasante F, Martínez-López EA, EspinosaChaurand LD, Cortés-Lara MC, Nolasco-Soria $\mathrm{H}$. Crecimiento y supervivencia del langostino (macrobrachium tenellum) en cultivos experimentales de verano y otoño en la costa tropical del pacífico mexicano. Trop Subtrop Agroecosyst 2011; 14(2):581-588.

10. Kuskoski EM, Asuero AG, Troncoso AM, Mancini-Filho J, Fett R. Aplicación de diversos métodos químicos para determinar actividad antioxidante en pulpa de frutos. Ciênc Tecnol Aliment 2005; 25(4):726-732.

11. Fish W, Perkins-Veazie P, Collins J. A quantitative assay for lycopene that utilizes reduced volume of organic solvents. J Food Compost and Anal 2002; 15:309-317.

12. Yasir I, Qin JG. Effect of light intensity on color performance of false clownfish, Amphiprion ocellaris cuvier. J World Aquac Soc 2009; 40(3):337-350.

13. Zar JH. Biostatistical analysis. ed. 5ta. New Jersey, USA: Ed. Prentice-Hall; 2009.

14. Ponce-Palafox J, Arredondo-Figueroa J, VernonCarter E. Carotenoids from plants used in diets for the culture of the pacific white shrimp (Litopenaeus vannamei). Rev Mex Ing Quím 2006; 5:157-165.

15. Gouveia L, Rema P, Pereira O, Empis J. Colouring ornamental fish (Cyprinus carpio and Carassius auratus) with microalgal biomass. Aquacult Nutr 2003; 9:123-129.

16. Yeşilayer N, Aral O, Karsli Z, Öz M, Karaçuha A, Yağci F. The effects of different carotenoid sources on skin pigmentation of Goldfish (Carassius auratus). The Israeli J Aquacult - Bamidgeh. 2011; 63(IIC:63.2011.523).
17. Ahilan B, Jegan K, Felix N, Ravaneswaran. Influence of botanical additives on the growth and colouration of adult Goldfish, Carassius auratus (Linnaeus). Tamil Nadu J Vet \&Animal Sci 2008; 4(4):129-134.

18. Wallat GK, Lazur AM, Chapman FA. Carotenoids of different types and concentrations in commercial formulated fish diets affect color and its development in the skin of the Red Oranda variety of Goldfish. N Am J Aquaculture 2005; 67:42-51.

19. Moreira RL, Da Costa JM, Teixeira EG, Moreira AGL, De Moura PS, Rocha RS and Vieira RHSF. Performance of Carassius auratus with different food strategies in wáter recirculation system. Arch Zootec 2011; 60(232):1203-1212.

20. Pérez RM, Vargas R, Martínez FJ, García EV, Hernández $\mathrm{B}$. Actividad antioxidante de los alcaloides de Bocconia arborea. Estudio sobre seis métodos de análisis. Ars Pharmaceutica 2003; 44(1):5-21.

21. Sinha A. and Oyas AA. China rose (Hibiscus rosasinensis) petals: a potent natural carotenoid source for goldfish (Carassius auratus L.). Aquac Res 2007; 38(11):1123-1128.

22. Orbe-Rogel JC. Elaboración de dietas adicionadas con cempaxúchitl (Tagetes erecta L.) y su efecto sobre el desarrollo del pez japonés (Carassius auratus L.). [Tesis maestría]. México: Instituto Politécnico Nacional, Centro de Desarrollo de Productos Bióticos; 2012.

23. Pérez-Escalante V, Aguirre-Guzmán G, VanegasEspinoza PE, Del Villar-Martínez A. Effect of Anthocyanin's Extract from flour of Roselle calyx (Hibiscus sabdariffa) on growth and pigmentation of Goldfish (Carassius auratus). Thai J Vet Med 2012; 42(1):107-111.

24. Farré G, Sanahuja G, Naqvi S, Bai C, Capell T, Zhu C, Christou P. Travel advice on the road to carotenoids in plants. Plant Sci 2010; 179(12):28-48.

25. Giuliano G, Tavazza R, Diretto G, Beyer P, Taylor A. Metabolic engineering of carotenoid biosynthesis in plants. Trends in Biotechnol 2008; 26(3):139-145.

26. Hata $M$ and Hata $M$. Carotenoid pigments in goldfish, VI. The effect of acth and phenylthiourea on the discoloration and the carotenoids metabolism. Camp Biochem Physiol A Comp Physiol 1973; 46(1):95-101.

27. Rajasingh $H$, Øyehaug $L$, Våge $D$, Omholt $S$. Carotenoides en la dinámica de salmón atlántico. BMC Biology 2006; 4:10. 